\title{
Szemle
}

\author{
BuJdos ÁGnEs*
}

\section{Vízjog (Aktuális kihívások a vizek jogi szabályozásában)}

2013 tavaszán jelent meg Szilágyi János Ede, a Miskolci Egyetem Állam- és Jogtudományi Kar Agrár- és Munkajogi Tanszéke egyetemi docensének könyve, Vízjog: Aktuális kihívások a vizek jogi szabályozásában címmel. A 262 oldal terjedelmü könyv egy TÁMOP kutatási program ${ }^{1}$ keretében készült el, és a Miskolci Egyetem gondozásában jelent meg.

\section{A téma aktualitása}

A víz mint létfontosságú és mással nem helyettesíthető természeti erőforrás jogi szabályozásának vizsgálatát a korlátozottan rendelkezésre álló mennyiség (mint édesvíz), illetve a szennyezés következtében fellépő minőségi problémák teszik aktuálissá globális, regionális és nemzeti szinten egyaránt. Nemzetközi szinten a vízhez kapcsolódó kérdések jelentőségét tükrözi többek között, hogy a 2000-ben 189 állam által elfogadott Milleniumi fejlesztési célok² egyike szerint „2015-ig a felére kell csökkenteni azoknak a számát, akik nem jutnak egészséges ivóvízhez vagy nem képesek azt megfizetni”. Az ENSZ a „Víz az életért” évtizednek nyilvánította a 20052015 közötti időszakot, illetve 2013 a vízügyi együttműködés nemzetközi éve volt, és 2013 októberében Magyarország adott helyet a Budapesti Víz Világtalálkozónak. Európai Közösségi szinten a 2000/60/EK sz. Vízkeretirányelv hozta a legnagyobb változást a víz szabályozása terén, amely úgy fogalmaz a vízzel kapcsolatban, hogy az „nem szokásos kereskedelmi termék, hanem örökség, amit annak megfelelően óvni, védeni és kezelni kell”. Érdeme továbbá, hogy összekapcsolja a víz mennyisé-

\footnotetext{
* Dr. Bujdos Ágnes doktorandusz, Debreceni Egyetem Állam- és Jogtudományi Kar Agrárjogi, Környezetjogi és Munkajogi Tanszék, bujdos.agnes@law.unideb.hu.

1 A program elöírásainak köszönhetően a könyvet az interneten is szabadon elérhetővé tették. http://jogikar. uni-miskolc.hu/projectSetup/files/kiadvanyok/nevtelen-melleklet-00020.pdf (letöltés: 2014. március 31.).

2 www.un.org/millenniumgoals.
} 
gi és minőségi oldalát, és a szabályozás alapját a vízgyűjtő kerületek képezik. Nemzeti szinten két okból is érdekes a vízre vonatkozó szabályozás vizsgálata. Egyrészt a vizeink 95\%-a határainkon túlról érkezik és 90\%-a el is hagyja az országot, így különösen fontosak a minőségi kérdések (emlékezzünk csak vissza a tiszai ciánszenynyezésre); másrészt az országon belül is számtalan probléma merült fel az utóbbi években a vizekkel kapcsolatban, a víziközmüvek privatizációja ${ }^{3}$ vagy az ország déli részén az ivóvizek magas arzéntartalma kapcsán. A fentieken túl egy kifejezetten a vízjogról szóló magyar nyelvű könyv megjelenése annál is inkább aktuális volt, mivel utoljára Bruhács János ${ }^{4}$ foglalkozott ilyen mélységben és terjedelemben a témával. Ráadásul ő elsősorban a nemzetközi közjog oldaláról közelítette meg a kérdéskört (így például a nemzetközi vízfolyásokra, a területi szuverenitásra, a nemzetközi jogalkotásra vagy a vizek szennyezésére vonatkozó szabályok alapján). Az ő munkáin kívül, a hazai tudományos életböl még Szappanyos Melinda vízhez való jogról szóló disszertációját, illetve az azt követően megjelenő monográfiáját érdemes megemlíteni, ezek azonban már Szilágyi János Ede kéziratának lezárását követően készültek el. ${ }^{5}$ A nemzetközi szakirodalomban szerencsére sokkal kedvezőbb a helyzet. Az édesvizekkel kapcsolatos kérdések vizsgálatának az elmúlt években több neves szerző is egy teljes könyvet szentelt, csak hogy néhány példát említsek: Elli Louka, Laurence Boisson de Chazournes és Owen Mclntyre. ${ }^{6}$

\section{Sajátos szerkezet}

A bevezetést követően öt érdemi fejezettel találkozhat az olvasó, ezt követi az összegzés, a könyv legvégén pedig az irodalomjegyzék található. A könyv szerkezetének vizsgálata kapcsán érdemes megemlíteni, hogy egy ilyen speciális, ugyanakkor több tudományághoz kapcsolódó téma jogi szempontú elemzése többféleképpen is elképzelhető. Először is kézenfekvőnek tűnhet a vízhez kapcsolódó szabályozásnak az egyes jogágak felöli megközelítése, például a polgári jog, a büntetőjog vagy a közigazgatási jog oldaláról. (Ezzel szemben a szerző szem elött tartja, hogy a vízhez kapcsolódó kérdések több jogághoz is kapcsolódnak, és nem korlátozza le a témát egy terület megközelítési módjára és szabályozására, pl. a polgári jogra

3 BELÉNYESI Pál: A vízszolgáltatások hatékonyságának javitása a Vízkeretirányelv egyes rendelkezései és a szennyező fizet elvének tükrében, PhD-értekezés. Debrecen, DE ÁJK, 2013.

4 BruHÁcs János: Nemzetközi vízjog: A nemzetközi folyóvizek nem hajózási célú hasznosításának joga. Budapest, Akadémiai Kiadó, 1986, illetve Uö: The law of non-navigational uses of international watercourses. Dordrecht; Boston: Martinus Nijhoff Publ., 1992.

5 Szappanyos Melinda: A vízhez való jog érvényesíthetősége az ENSZ keretében, PhD-értekezés, 2012, Pécs; Uö: Víz és jog: A vízhez való jog érvényesithetősége az ENSZ keretében. Veszprém, Veszprémi Humán Tudományokért Alapítvány, 2013.

6 LOUKA, Elli: Water law \& policy: governance without frontiers. Oxford, New York, Oxford University Press, 2008; BoIsson de Chazournes, Laurence: Fresh Water in International Law. New York, Oxford University Press, 2013; Boisson de Chazournes, Laurence-LeB, Christina-Tignino, Mara (ed.): International law and freshwater: the multiple challenges. Cheltenham, UK, Northampton, MA, USA, Edward Elgar, 2013; McINTYRE, Owen: Environmental protection of international watercourses under international law. Aldershot, England, Burlington, VT, Ashgate, 2007. 
vagy a környezetjogra.) Másodszor megközelíthető a kérdés a vízhez kapcsolódó legfontosabb kérdések nemzetközi, európai uniós és nemzeti szintű bemutatásával, vagy éppen a nemzetközi (globális és regionális) szint, az Európai Unió és Magyarország szempontjából a legaktuálisabb problémák vizsgálatával. Harmadszor, mivel az egyes fejezetekben nagy hangsúlyt fektet a szerző az egyes jogintézmények kialakulására ( $p l$. A víz mint a tulajdonjog tárgya), ezért ez a történeti szemléletmód akár az egész könyvet meghatározhatta volna, azonban ez, a tételes jogi munkákban is gyakran alkalmazott megközelítés az aktuális jogi problémák kezelésére kevéssé lett volna alkalmas. Végezetül, egy további lehetőségként kínálkozott a témának a mennyiségi és minőségi vízvédelem kérdései, vagy éppen a felszíni és felszín alatti vizekre vonatkozó szabályozás elhatárolása szerinti megközelítése is, akárcsak az egyes föbb felhasználókhoz (akik egyben a főbb szennyező források is) - mint a háztartások, az ipar és a mezőgazdaság - kapcsolódó problémák és szabályok bemutatása. Szilágyi azonban sajátos megoldást választott. Bizonyos kérdéseket, amelyeket kiemelt fontosságúnak tart, és nem csak hazai viszonylatban bírnak jelentőséggel, mind a három (nemzetközi, EU s nemzeti) szinten vizsgál, míg más kérdések (pl. a víziközmü-szolgáltatások) kapcsán a magyar szabályozás áll a középpontban.

Rátérve a könyv egyes témaköreinek bemutatására, a Vízjogi alapvetések címet viselő első fejezet a vízkörforgás bemutatásával kezdődik, majd a vizekhez kapcsolódó nemzetközi, európai uniós és magyar kihívások elemzésével folytatódik. Ezzel a szerző a vízre mint természeti erőforrásra, annak tulajdonságaira és jelentőségére hívja fel a figyelmet. Ez összhangban áll a már előbb említett problémaorientált megközelítésmóddal.

A második fejezet, A víz mint a tulajdonjog tárgya, a magyar jogra vonatkozó szabályokra és azok fejlődésére helyezi a hangsúlyt, a vizekre vonatkozó római jogi szabályok és a két legnagyobb jogcsalád, a római-germán és a common law szabályainak rövid áttekintését követően.

A harmadik fejezet $A$ víz mint környezeti elem és természeti erőforrás címet viseli. A fejezet nemzetközi szinten a vízre vonatkozó multilaterális és bilaterális megállapodásokat tartalmazza, európai uniós szinten pedig a vizekre vonatkozó közösségi szabályok kialakulása és a vízkeretirányelv áll a középpontban. A magyar rész elsősorban az Alaptörvény, a vízgazdálkodásról szóló törvény és a felszíni és a felszín alatti vizek védelméről szóló kormányrendeletek követelményeiről szól, végezetül az egyes ágazatokhoz (pl. energia, közlekedés) kapcsolódó kérdésekre helyeződik a hangsúly. Szerkezetileg érdekes megoldás, hogy miután az első fejezet a vízkörforgás bemutatásával, a vizet természeti erőforrásként közelíti meg, addig a második fejezet a tulajdonjog tárgyaként határozza meg azt, majd a harmadik fejezet ismét természeti erőforrásként tekint a vízre.

A negyedik fejezet $A$ víz mint kereskedelmi ügyletek tárgya: áru, illetve szolgáltatás címet viseli. Ez a rész a víznek mint árunak és szolgáltatásnak a bemutatásával kezdődik, majd ezt követően a víziközmü-szolgáltatások kerülnek a középpontba. Ez utóbbi témát egyrészt a nemzetközi privatizáció szempontjából, másrészt a magyar víziközmű-szolgáltatás átszervezése oldaláról ismerhetjük meg. 
Az ötödik fejezet tárgyát $A$ víz egyéb jogi koncepciói képezik. A fejezet érdekességét az adja, hogy a korábbiakkal ellentétben nem egy téma feldolgozására vállalkozik, hanem olyan kérdésekről ad rövid áttekintést, amelyek részletes kifejtésére e könyv keretei között már nem volt lehetőség, azonban jelentőségüknél és aktualitásuknál fogva mindenképpen említést érdemelnek (ilyen például a vízhez való jog emberi jogi megközelítése).

Az Összegzés felépítése szintén sajátosnak mondható, mivel először a vízre vonatkozó általános következtetéseket von le a szerző, és csak ezt követően kerül sor konklúziók megfogalmazására egyes problémákra vonatkozóan. Noha ezek nem feltétlenül fednek le egy-egy teljes fejezetet (pl. a víz mint szolgáltatás tárgya esetében), így bár nem szokványos, logikailag mégis elfogadható ez a megoldás.

\section{Tartalmi áttekintés}

A szerző már a könyv elején utal rá, hogy a vízhez kapcsolódó kérdések jelentőségéből és szerteágazóságából adódóan, a kötetnek nem lehet célja a téma (a vízjog) teljes körü feldolgozása, ezért, bár igyekszik átfogó képet nyújtani az olvasó számára, mégis elsősorban a magyar társadalmat érintő kihívásokra, illetve az azokra adandó lehetséges megoldásokra kíván koncentrálni. A kötet fókuszában a víznek a következő megközelítési módjai állnak: a víz mint környezeti elem és természeti erőforrás, illetve a tulajdonjog és a kereskedelmi ügyletek tárgya. Ezek az egymástól eltérő területek teljesen különböző megközelítést igényelnek, ennek megfelelően jelentős módszertani eltérések figyelhetőek meg a könyv egyes részei között. Következésképpen a módszertan mindig az adott témához kapcsolódik. Tekintettel arra, hogy már az alcímből is következtetni lehet rá, hogy a könyv csak a vízzel kapcsolatos „aktuális kihívásokra” koncentrál, ezért a szerző a történeti módszerhez csak olyan mélységben nyúl, amennyire azt az adott téma megkívánja (I. 1. pont). Ez alól talán az egyetlen kivételt $A$ víz mint tulajdonjog tárgya c. fejezetnek a magyar szabályozásra vonatkozó része jelenti, ahol a szerző kifejezett célja a szabályozás fejlődésének bemutatása. A monográfia egészére a legjellemzőbb a problémaorientált módszer, amely alapvetően meghatározza az egyes kérdések vizsgálatának mélységét és szintjét. Jelen van ezenkívül az összehasonlító jogi szemlélet is ( $p l$. a common law és a római-germán jogcsalád vizekre vonatkozó szabályozásának bemutatása, vagy a víziközmü-szolgáltatások privatizációjának nemzetközi dimenziója). Külön kiemelendő a vízhez kapcsolódó kérdések interdiszciplináris szemléletű feldolgozása, amely abban is megnyilvánul, hogy bár végig a jogi megközelítés dominanciája figyelhető meg, a téma jellegére való tekintettel mégis a bevezetést követő első érdemi fejezet hidrológiai tárgyú. Véleményem szerint, noha a szerző célja alapvetően a magyar kérdések vizsgálata, jó érzékkel találja meg az egyensúlyt a nemzetközi, a közösségi és a nemzeti szabályok bemutatása között. Ennek eredményeképpen adott esetben a nemzetközi és európai uniós részek a hazaival azonos vagy legalábbis ahhoz hasonló terjedelemben és hangsúllyal kerülnek bemutatásra. (PI. a vízhez kapcsolódó globális és közösségi kihívások bemutatása, a víz mint környezeti elem védelme a nemzetközi és a közösségi jogban, illetve a 
vízhez való jog mint emberi jog.) A könyv egészét meghatározza a rendszerszemléletü gondolkodásmód, amely különösen az egyes fejezeteken belül érvényesül, de ez érvényesül abban is, hogy a kötet elején részletesen bemutatott vízkörforgásra időről időre visszautal a szerző a későbbi fejezetekben.

A könyv érdemei közé tartozik továbbá az is, hogy olyan témák is helyet kaptak benne, amelyek nemcsak aktuálisak, hanem a magyar szakirodalomban kifejezetten újnak mondhatók (ilyen pl. a virtuális víz kérdése). Örömmel vennénk, ha a szerző jövőbeni, további elemzéseinek tárgyát képezné a könyv egyes fejezeteiben elemzett jogintézmények egymás közötti kapcsolatának vizsgálata (hiszen például már jelentős nemzetközi jogi szakirodalma van a víz mint árucikk és a vízhez való emberi jog egymáshoz való viszonyának), Magyarország tekintetében pedig a vízszennyezéshez kapcsolódó jogi problémák vagy a víziközmű-szolgáltatók integrációjának környezetjogi kérdései. ${ }^{7}$

\section{A kötet felhasználhatósága}

A könyv nyelvezetét alapvetően meghatározza, hogy a szerző a jogi megközelítés ellenére azt nem csak a jogászoknak szánta. Ennek megfelelően a jogi terminológia igényes és következetes alkalmazása mellett is olvasmányos, könnyen követhető a stílusa. Figyelemre méltó a felhasznált források nagy száma, az idegen nyelvű (elsősorban angol nyelvű) források aránya és a források sokszínűsége. A nemzetközi és közösségi részek nagy számban hivatkoznak nemzetközi egyezményekre, ENSZdokumentumokra, nemzetközi szervezetek (pl. a World Water Council) nyilatkozataira, programokra (pl. World Water Assessment Programme), illetve a közösségi intézmények jogforrásaira egyaránt. A hazai jogra vonatkozó szabályok bemutatása során a jogszabályok széles körét használja, illetve ezeken túlmenően alkotmánybírósági határozatok és ezekhez kapcsolódó különvélemények és a jövő nemzedékek országgyűlési biztosának állásfoglalása is megtalálhatók. A lábjegyzetek nemcsak a meghivatkozott dokumentumokra utalnak, hanem nagy számban találhatóak a további kutatást elősegítő szakirodalomra és forrásokra való hivatkozások is. Ehhez egyébként az is segítséget nyújt az olvasó számára, hogy sok esetben a magyar terminológia mellett az eredeti szakkifejezést is megadta a szerző.

A téma aktualitásánál és szerteágazóságánál fogva a könyv a legkülönfélébb szakemberek érdeklődésére tarthat számot. A jogászok közül elsősorban a környezetjog és a polgári jog iránt érdeklődők, illetve a vízzel kapcsolatos kérdésekre nyitott közösségi joggal és nemzetközi joggal foglalkozó jogászok számára ajánlható. Az egyéb, mindenekelőtt vízügyi területen dolgozó szakemberek számára pedig a vízhez kapcsolódó kérdések jogi szempontú megközelítése nyújthat új és hasznos ismereteket.

7 A víziközmü-szolgáltatók integrációjának egyes jogi kérdéseivel a szerző épp folyóiratunk ezen lapszámában foglalkozik (a szerk.). 